УДК 347.9

DOI https://doi.org/10.32849/2663-5313/2020.8.07

Любов Малярчук,

канд. юрид. наук,

дочент кафедри нотаріального та виконавчого прочесу і адвокатури

Киівського начіонального університету імені Тараса Шевченка

\title{
Олександр Снідевич,
}

канд. юрид. наук, дочент,

дочент кафедри нотаріального та виконавчого прочесу і адвокатури

Київського національного університету імені Тараса Шевченка

\section{СУБ'СКТИ ВИКОНАВЧОГО ПРОВАДЖЕННЯ: ЗАКОНОПРОЕКТНІ НОВЕЛИ}

У статті здійснювався науковий аналіз особливостей врегулювання інституту суб'єктів виконавчого провадження за проектом Закону про виконавче провадження (№ 3726) у порівнянні із чинним Законом Украӥни «Про виконавче провадження».

Розглянуті положення законопроекту, в яких до суб'єктів виконавчого провадження пропонується віднести учасників виконавчого провадження та осіб, які залучаються до проведення виконавчих дій, та наведений перелік осіб, що входять до їх числа. Встановлено, що у використаній класифікаиї не прослідковується чіткий критерій поділу усіх суб'єктів виконавчого провадження на групи учасників виконавчого провадження. Наведений ряд наукових класифікачій суб'єктів виконавчого провадження, які грунтуються на підходах щодо поділу учасників прочесу на юридично заінтересованих у результатах процесу осіб та осіб, юридично незаінтересованих, але які не взяті до уваги в законопроекті.

Визначена відсутність чіткого врегулювання в законопроекті правового становища виконавия в порівнянні з іншими суб'єктами виконавчого провадження, адже він перестав займати однакове місие у системі суб'єктів виконавчого провадження, що в цілому визнано правильним. Однак піддано критииі той факт, що усі права та обов'язки виконавия (які стосуються усіх стадій виконавчого провадження) передбачені у главі, що врегульовує лише одну зі стадій виконавчого провадження - відкриття виконавчого провадження.

Резюмовано, що правовий статус досить значного кола суб'єктів виконавчого провадження залишається невирішеним. Так, потребує самостійного окреслення правовий статус особи, в якої перебуває майно боржника чи майно та кошти, належні боржникові від інших осіб, особи-власники майна, що знаходиться у житлі, у якому проживає боржник, чи особи, які проживають разом з боржником. В аспекті иих осіб на вирішення винесена проблема виключення їх із кола тих суб'єктів, які вправі оскаржити рішення, дії або бездіяльність державних та приватних виконавиів, шляхом надання права на оскарження загалом всім особам, чиї права потребують захисту в результаті вчинення виконавчих дій.

Ключові слова: учасники виконавчого провадження, особи, які залучаються до проведення виконавчих дій, виконавець, прокурор, поняті, представник.

Постановка проблеми. Початок розвитку наявної системи примусового виконання рішень в сучасній Україні пов'язується із Законом України «Про виконавче провадження» 1999 року. Оцінюючи через більш ніж двадцять років стан правового регулювання виконавчого провадження в Україні, зауважимо, що він став тим Законом, окремі недосконалі положення якого ще й досі визначають зміст сучасного законодавства про виконавче провадження. Як і інша його редакція 2010 року, так і чинний на сьогодні Закон «Про виконавче провадження» 2016 року грунтувалися та грунтуються на структурі, змісті та термінології Закону
1999 року. Кажучи простіше, багато їх положень $€$ банальним переписуванням попереднього, не завжди якісного законодавства.

Упродовж останніх місяців у спільноті правників загострилася дискусія щодо реформування законодавства про виконавче провадження. Свій проект Закону про виконавче провадження, розроблений за участі Асоціації приватних виконавців, нещодавно був внесений також і народними депутатами Т.П. Тарасенком та С.О. Демченком (№ 3726 від 23.06.2020) [1]. Аналіз окремих його положень щодо інституту суб'єктів виконавчого провадження свідчить про те, що він містить окремі концептуальні недо- 
ліки, не враховує надбання науки виконавчого процесу.

Стан дослідження. Окремі правові проблеми, пов'язані з урегулюванням у законодавстві інституту учасників виконавчого провадження, досліджували А.М. Авторгов, Ю.В. Білоусов, І.В. Бондар, М.В. Вінциславська О.О. Дерій, П.П. Заворотько, О.М. Кузнець, Л.С. Малярчук, М.П. Омельченко, О.С. Снідевич, Н.А. Сергієнко, С.Я. Фурса, С.І. Фурса, М.Й. Штефан, С.В. Щербак та інші. Зазначені праці є основою проведеного дослідження.

Метою статті $є$ проведення наукового аналізу особливостей врегулювання інституту суб̆'єктів виконавчого провадження у проекті Закону про виконавче провадження (реєстраційний № 3726 від 23.06.2020) внесеного народними депутатами України Т.П. Тарасенком та С.О. Демченком, окреслення недоліків такого врегулювання та висловлення пропозицій, спрямованих на покращення правової регламентації цього інституту у законодавстві України п про виконавче провадження

Виклад основного матеріалу. Не заперечуючи необхідність розробки якісно нового Закону «Про виконавче провадження» (а можливо навіть й Виконавчого кодексу України), мусимо констатувати, що, на жаль, проект Закону про виконавче провадження (реєстраційний № 3726 від 23.06.2020) в окремих його положеннях знову є копією недосконалого попереднього законодавства. Він залишає очевидно не прийнятні ані 3 точки зору науки, ані з точки зору практики положення, що стосується інституту суб'єктів виконавчого провадження.

Глава 3 Розділу IV «Загальні засади здійснення виконавчого провадження» законопроекту має назву «Суб'єкти виконавчого провадження». Такими суб'єктами відповідно до ст. 57 проекту є учасники виконавчого провадження та особи, які залучаються до проведення виконавчих дій. Хто відноситься до учасників виконавчого провадження - із законопроекту вбачається. Такими є сторони, прокурор, експерт, спеціаліст, перекладач, суб'єкт оціночної діяльності - суб'єкт господарювання, особи, права інтелектуальної власності яких порушені. Однак хто ж є особами, які залучаються до проведення виконавчих дій? Відповіді на це питання, не дивлячись на свою назву, стаття не дає. Ї̈ї можна знайти вже у ст. 63 проекту, яка має назву «Залучення інших осіб до проведення виконавчих дій». Такими особами є представники органів опіки і піклування, інших органів та установ, а також суб'єкти господарювання, які можуть залучатися виконавцем на договірних засадах у визначених Законом випадках.

Насамперед зауважимо, що одразу ж викликає несприйняття віднесення того чи іншого суб'єкта виконавчого провадження до тієї чи іншої групи. Це зумовлюється тим, що у використаній класифікації не прослідковується чіткий критерій поділу усіх суб'єктів виконавчого провадження на групи учасників виконавчого провадження та осіб, які залучаються до проведення виконавчих дій. Мусимо констатувати, що ця проблема існує ще з 1999 року, коли відповідний Закон «Про виконавче провадження» також поділив усіх учасників виконавчого провадження (саме так їх називала відповідна глава 2 Закону) на учасників виконавчого провадження та осіб, які залучаються до проведення виконавчих дій. Учасниками виконавчого провадження були визнані державний виконавець, сторони, представники сторін, експерти, спеціалісти, перекладачі, а особами, які залучаються до проведення виконавчих дій, - поняті, працівники органів внутрішніх справ, представники органів опіки і піклування, інших органів і установ у порядку, встановленому цим Законом. Фактично аналогічний підхід до класифікації суб'єктів виконавчого провадження містило й подальше законодавство про виконавче провадження аж до чинного Закону включно.

$\mathrm{y}$ науці виконавчого процесу вже давно викликає несприйняття такий підхід до класифікації суб'єктів виконавчого провадження, оскільки він не містить під собою наукового підгрунтя. Як справедливо зазначає С.В. Щербак, учасниками виконавчого провадження мають бути лише ті особи (фізичні, юридичні, громадяни-підприємці), які мають заінтересованість у результатах виконавчого провадження (особисту, державну, службову) і роль яких є активною у провадженні щодо виконання рішень, тобто вони можуть впливати на процес вчинення виконавчих дій. Усі ж інші особи - не учасники, а суб'єкти виконавчого провадження, оскільки вони не заінтересовані в його результаті, а лише сприяють проведенню виконавчих дій. Їхня роль у виконавчому провадженні не активна, а пасивна [2, с. 227].

У процесуальному законодавстві та процесуальній науці використовується загальновизнаний та чіткий поділ учасників процесу на юридично заінтересованих у результатах процесу осіб (у судовому процесі ці особи раніше мали назву осіб, які беруть участь у справі, а сьогодні законодавство називає їх учасниками справи) та осіб, юридично незаінтересованих (які називалися або ж особами, які сприяли вирішенню справи, або 
ж як на сьогодні - інші учасники судового процесу). Виходячи із цього, ціла низка науковців пропонує свої класифікації суб'єктів виконавчого провадження, які тією чи іншою мірою б враховували ці підходи.

Так, наприклад, С.В. Щербак запропонувала поділити усіх суб'єктів виконавчого провадження на: 1) органи і посадові особи державної виконавчої служби; 2) учасників виконавчого провадження (сторони та їхні представники, органи державної влади і місцевого самоврядування, прокурор, який представляє інтереси держави або особи); 3) осіб, які залучаються до проведення виконавчих дій (спеціалісти, перекладачі, поняті, зберігачі майна боржника, спеціалізовані організації, що здійснюють оцінку та реалізацію майна боржника) [3, с. 84]. Р.В. Ігонін поділяє суб'єктів виконавчого провадження на такі категорії, як: 1) основні учасники виконавчого провадження (державний виконавець, сторони та їхні представники, органи державної влади та місцевого самоврядування, прокурор, який представляе інтереси держави або особи); 2) особи, які залучаються до проведення виконавчих дій (спеціалісти, перекладачі, поняті, зберігачі майна боржника, спеціалізовані організації, що здійснюють оцінку та реалізацію майна боржника); 3) особи, які сприяють виконавчому провадженню (суд, Державна виконавча служба) [4, с. 52]. Д.М. Сибільов ділить учасників виконавчого провадження на три групи: 1) державні виконавці, 2) особи, що мають особисту юридичну заінтересованість у виконанні рішення, до яких відносить сторони виконавчого провадження та їх представників, 3) особи, що сприяють виконанню рішень, до яких належать, на його думку, експерти, спеціалісти, перекладачі, поняті, та інші особи, перераховані в ч. 2 ст.10 Закону «Про виконавче провадження» [5, с. 18] тощо.

Загалом викликає здивування постійне несприйняття такого підходу до класифікації суб'єктів виконавчого провадження в розробників чергового законодавства про виконавче провадження, хоча будь-яких обгрунтованих підстав для цього не вбачається.

Як і у чинному Законі «Про виконавче провадження», так і в законопроекті бачимо, що прокурор міститься в одній групі суб'єктів (учасників) виконавчого провадження, а орган опіки та піклування - в іншій, не дивлячись на те, що функціональні основи їх участі як у суді, так і надалі у виконавчому провадженні $€$ досить близькими. Взагалі незрозумілим $є$ й те, чому у чинному Законі спеціаліст, експерт чи перекладач попали в одну групу учасників виконавчого прова- дження, а, наприклад, представник поліції чи понятий - в іншу. Прикро, що аналогічні питання виникають і під час ознайомлення зі змістом запропонованого законопроекту. I це не дивлячись на те, що, наприклад, право виконавця у п. 14 ч. 1 ст. 73 законопроекту визначено як право залучати в установленому порядку працівників поліції, інших осіб, а також експертів, спеціалістів, а для проведення оцінки майна - суб'єктів оціночної діяльності - суб'єктів господарювання, що свідчить про їх однакове місце у структурі суб'єктів виконавчого провадження.

Не досить вдало запропоновано в законопроекті врегулювати і правове становище виконавця. Так, у порівнянні із чинним законодавством у проекті виконавець перестав займати однакове місце у системі суб'єктів виконавчого провадження поряд з іншими його суб'єктами, оскільки вже згадана глава 3 законопроекту не містить положень про правове становище виконавця. Це є досить правильнимпідходом, оскільки місце виконавця у цій системі піддавалося критиці у науці вже давно [2, с. 226]. Очевидно, що такий підхід $є$ продовженням підходу законодавця до врегулювання становища суду як обов'язкового суб'єкта процесуальних правовідносин у судочинстві (нагадаємо, що жоден із чинних процесуальних кодексів, що врегульовує позакримінальне судочинство, не містить суд як учасника процесу). Піддамо критиці те, що положення про права та обов'язки виконавця (які стосуються усіх стадій виконавчого провадження) містяться у главі, що врегульовує лише одну зі стадій виконавчого провадження, а саме у главі 1 «Відкриття виконавчого провадження» розділу $\mathrm{V}$ «Стадії та порядок здійснення виконавчого провадження». На наш погляд, такий підхід виглядає принаймні нелогічним. При цьому також звернемо увагу, що вже згадані процесуальні кодекси містять відповідні глави про склад суду та відводи саме перед відповідними главами про учасників судового процесу. Відтак доцільно було б відповідні положення про правове становище виконавця помістити в законопроекті перед положеннями про суб'єктів виконавчого провадження.

Тепер щодо повноти врегулювання в запропонованому законопроекті інституту суб'єктів виконавчого провадження.

Не дивлячись на те, що глава 3 законопроекту охоплює правовим регулюванням значно ширше коло суб'єктів виконавчого провадження у порівнянні із чинним Законом «Про виконавче провадження», питання щодо правового статусу досить значного кола суб'єктів виконавчого провадження залишається невирішеним. 
Так, на наш погляд, потребує самостійного окреслення у відповідній главі «Суб'єкти виконавчого провадження» законопроекту правовий статус особи, в якої перебуває майно боржника чи майно та кошти, належні боржникові від інших осіб. У зазначених осіб внаслідок існування виконавчого провадження щодо боржника виникає значне коло обов'язків, а виконавець набуває значних прав на втручання в їх сферу правових інтересів. Однак правовий статус таких осіб, насамперед у частині їхніх прав, не окреслено.

Значні юридичні ризики у виконавчому провадженні несуть особи-власники майна, що знаходиться у житлі, у якому проживає боржник, чи особи, які проживають разом з боржником. Фактично для них опис майна боржника за їх місцем проживання - це подібно до обшуку у кримінальному провадженні. Однак, знову ж таки, їхній правовий статус як суб'єктів виконавчого провадження ані у відповідній главі законопроекту, ані загалом у законопроекті не врегульовано. Мусимо визнати, що цей недолік має й чинне законодавство.

В аспекті цих осіб досить характерною $€$ й проблема виключення їх із кола тих суб’єктів, які вправі оскаржити рішення, дії або бездіяльність державних та приватних виконавців.

Так, як убачається зі ст. 127 та 128 законопроекту, ними є лише сторони та інші учасники виконавчого провадження. Такий підхід виглядає хибним. Так, як зазначалося в науці, в силу різних причин можливе порушення прав і інших осіб, які особисто не беруть участі у примусовому виконанні рішення. Для прикладу, бувають ситуації, коли арешт накладається на майно особи, що належить їй, а не боржникові, і в такому разі вона може лише звернутися до суду 3 позовом про визнання права власності на це майно і про зняття з нього арешту. Оскаржується постанова виконавця про накладення арешту, але за особами, що не є суб'єктами виконавчого провадження, не закріплене таке право. Вони мають застосовувати загальні правила визначення юрисдикції суду, до компетенції якого належить розгляд цього питання в позовному порядку, відповідно, і його вирішення не відбуватиметься за скороченими строками, що не вигідно для власника майна, на яке накладено обтяження, коли факт права власності є безспірним, але ігнорується виконавцем. 3 огляду на зазначене до переліку суб'єктів, які вправі порушити судовий розгляд скарги щодо виконавців у встановленому ст. 74 Закону порядку, варто відносити всіх осіб, чиї права потребують захисту в результаті вчинення виконавчих дій [6, с. 161]. Відтак доцільно було б запобігти наведеним недолікам законодавчих положень у майбутньому.

Пункт 2 ч. 1 ст. 73 законопроекту передбачає, що виконавець під час здійснення виконавчого провадження має право проводити перевірку виконання юридичними особами незалежно від форми власності, фізичними особами, фізичними особами підприємцями рішень стосовно працюючих у них боржників. Однак, як і в попередньому випадку, правовий статус цих осіб як суб'єктів виконавчого провадження в законопроекті також не визначено. Потребує свого врегулювання в окремих положеннях глави 3 законопроекту й правовий статус багатьох інших осіб, що залучаються у виконавче провадження.

Більш детальніше, на наш погляд, слід було б також розмежувати правовий статус експерта та спеціаліста. У законопроекті, як i у чинному Законі, протягом усього змісту правовий статус експерта врегульовується разом з правовим статусом спеціаліста. Відтак критерії розмежування їхнього правового статусу не прослідковуються, не дивлячись на те, що залучення таких осіб у виконавче провадження є не досить дешевим задоволенням, за яке врешті-решт вимушений платити боржник.

Виглядає помилковим й підхід щодо відмови від участі у виконавчому провадженні понятих. Аналізуючи питання щодо доцільності відмови від понятих, М.В. Вінциславська обгрунтовано зазначає, що під час примусового входження до жилих будинків i квартир поняті є додатковою гарантією дотримання процесуальних прав осіб, які беруть участь у виконавчих діях, це додаткова гарантія захисту як державного виконавця, так і боржника і стягувача від безпідставних скарг і позовів [7, с. 302]. Безумовно, необхідність залучення понятих до участі у виконавчих діях створює певні незручності для виконавців, однак хочемо наголосити, що ix існування у виконавчому провадженні -в інтересах самих виконавців. Участь понятих є запорукою запобігання безпідставних звинувачень виконавця у тих же крадіжках майна під час опису.

Загалом же вбачається, що значна кількість положень законопроекту в частині суб'єктів виконавчого провадження є переписуванням положень попереднього законодавства. Не заперечуємо того, що більшість із них є положеннями належної якості. Однак не можемо не звернути увагу на ще одне очевидно недосконале положення, яке запропоноване в законопроекті. 
Так, ч. 1 ст. 60 законопроекту містить положення про те, що особиста участь фізичної особи у виконавчому провадженні не позбавляє її права мати представника, крім випадку, коли боржник згідно з рішенням зобов'язаний вчинити певні дії особисто. Порівняльний аналіз цього положення 3 попереднім законодавством показує, що це положення є майже дослівною редакцією недосконалого за своїм змістом відповідного положення ще аж першого Закону «Про виконавче провадження» 1999 року і яке наявне і у чинному Законі.

Однак, аналізуючи зазначене положення законодавства, О.О. Дерій справедливо зазначає, що якщо буквально тлумачити цю статтю, то вбачається, що боржник у випадку, якщо згідно 3 рішенням він зобов'язаний вчинити певні дії особисто та особисто бере участь у виконавчому провадженні, не може мати представника навіть для реалізації своїх прав, передбачених законодавством. Разом із тим якщо боржник у випадку, що розглядається, не приймає особисто участь у виконавчому провадженні, то права на представника він має. На її погляд, краще було б прописати дану норму таким чином, що боржник не має права діяти через представника в частині виконання обов'язку, покладеного рішенням на нього особисто, а не заборонити йому мати представника взагалі [8, с. 69]. Таким чином, боржник у виконавчому провадженні має багато процесуальних прав, здійснення чи виконання яких можливе через представника, як то: право на ознайомлення 3 матеріалами виконавчого провадження, право робити з них виписки, знімати копії, право заявляти відводи, право оскаржувати рішення, дії або бездіяльність виконавця тощо. Немає жодних перешкод для того, щоб боржник міг реалізувати зазначені права через представника. Наявну на сьогодні редакцію ч. 1 ст. 16 Закону «Про виконавче провадження» можна тлумачити як таку, що обмежує права боржника на правову допомогу адвоката у таких виконавчих провадженнях [9, с. 94]. Не дивлячись на те, що відповідний виняток з загального правила про право мати представника у виконавчому провадженні сформульований очевидно неправильно, він залишається незмінним у законопроекті.

\section{Висновки}

Не будемо заперечувати того, що проект Закону про виконавче провадження (реєстраційний № 3726 від 23.06.2020) містить багато необхідних новел і у разі його прийняття значно поліпшить правове регулювання виконавчого провадження. Однак, як i чинний на сьогодні Закон України «Про виконавче провадження», зазначений законопроект містить концептуальні недоліки стосовно врегулювання суб'єктів виконавчого провадження. Вважаємо, що не варто в новому Законі «Про виконавче провадження» в черговий раз переписувати окремі положення попереднього законодавства сумнівної якості. Для створення дієвої процедури примусового виконання рішень необхідно розробити дійсно якісний нормативний акт, який би грунтувався на належній теоретичній основі виконавчого процесу.

\section{Список використаних джерел:}

1. Проект Закону про виконавче провадження № 3726 від 23.06.2020. URL : http:// w1.c1.rada.gov.ua/pls/zweb2/webproc4_1?id=\&pf $3511=69256$

2. Фурса С.Я., Фурса Є.I., Щербак С.В Закони України «Про державну виконавчу службу», «Про виконавче провадження», «Про виконання рішень та застосування практики Європейського суду з прав людини» : наук.-практ. комент.; за заг. ред. С.Я. Фурси. Київ : КНТ, 2008. $1172 \mathrm{c}$.

3. Щербак С.В. Адміністративно-правове регулювання виконавчого провадження в Україні : дис... канд. юрид. наук: 12.00 .07 ; НАН України, Інститут держави і права ім. В.М. Корецького. Київ, 2002. 228 с.

4. Ігонін Р.В. Організаційно-правові засади діяльності суб'єктів виконавчого провадження : дис... канд. юрид. Наук : 12.00 .07 ; Національна академія держ. податкової служби України. Ірпінь, 2007. $211 \mathrm{c}$.

5. Сибилев Д.М. Закон Украины «Об исполнительном производстве» : Научно-практический комментарий. Харьков : Легас, 2000. 112 с.

6. Малярчук Л.С. Нові правила оскарження рішень, дій або бездіяльності виконавців під час звернення стягнення на майно боржника: переваги та недоліки. Часопис Київського університету права. 2018. № 2. С. 160-164.

7. Вінциславська М.В. Поняті та їх роль у виконавчому провадженні. Держава і право. Юридичні і політичні науки. 2013. Вип. 59. С. 298-302.

8. Дерій О.О. Актуальні питання представництва сторін виконавчого провадження адвокатом. Цивілістична процесуальна думка. 2016. № 5. C. $68-71$.

9. Снідевич О.С. Проблемні питання представництва у виконавчому провадженні України. Jurnalul juridic national: teorie şi practică. 2019. № 3. Ч. 1. С. 93-96. 


\section{Liubov Maliarchuk, Oleksandr Snidevych. Subjects of execution proceedings: new law} drafting

The article presents a scientific analysis of the features of the settlement of the institution of subjects of enforcement proceedings as under the draft Law on Enforcement Proceedings (No. 3726) in comparison with the current Law of Ukraine "On Enforcement Proceedings".

The provisions of the draft law are considered, in which participants in enforcement proceedings and persons involved in enforcement actions are proposed to be considered subjects of enforcement proceedings, and a list of included persons is given. It is established that the currently used classification does not contain a clear criterion to divide all subjects of enforcement proceedings into groups of parties in enforcement proceedings. Some scientific classifications of subjects of enforcement proceedings are given, which are based on approaches to the division of parties in the process into those legally interested in the outcome of the litigation and persons who are not legally interested, who, however, are not taken into account in the draft law.

It is pointed out that the legal status of the executer in comparison with other subjects of enforcement proceedings is not clearly regulated in the draft law, because they no longer occupy the same place in the system of subjects of enforcement proceedings, which is generally recognized as correct. However, it is criticized that all the rights and obligations of the executer (which apply to all stages of enforcement proceedings) are provided in the chapter that regulates only one stage of enforcement proceedings, namely, the opening of enforcement proceedings.

It is summarized that the legal status of a significant number of subjects of enforcement proceedings remains undetermined. For instance, the legal status of the person in whose custody the debtor's property or property and funds belonging to the debtor from other persons is, persons who own the property in the housing where the debtor resides, or persons living with the debtor needs to be defined separately. With respect of these persons are considered, the problem of excluding from them the subjects who have the right to appeal against decisions, actions or omissions of public and private executers, by granting the right of appeal to all persons whose rights need protection as a result of enforcement actions, should be considered.

Key words: participants in enforcement proceedings, persons involved in enforcement actions, an executer, a prosecutor, witnesses, a representative. 